\title{
Neonatal and maternal postpartum bacteroides bacteremia
}

\author{
Nahid Zaker $\mathrm{MD}^{1,2}$, Joy Lertzman $\mathrm{RN}^{1,2}$, Joanne Embree MD FRCPC ${ }^{1,2}$
}

\begin{abstract}
N Zaker, J Lertzman, J Embree. Neonatal and maternal postpartum bacteroides bacteremia. Can J Infect Dis $1999 ; 10(5): 358-361$.

OBJECTIVE: A unique case of Bacteroides fragilis bacteremia in a mother and her infant prompted a review of these infections in neonates and postpartum mothers during a five-year period at two institutions in Winnipeg, Manitoba. The purpose was to determine the frequency of these infections and ascertain commonly associated factors.

METHODS: Infants and postpartum mothers diagnosed with bacteroides bacteremia were identified from laboratory records in both hospitals, and their medical charts were retrospectively reviewed.

RESULTS: Bacteroides species were isolated in 10 maternal and four neonatal blood cultures. This represented $8.1 \%$ of the positive maternal and $1.2 \%$ of the positive neonatal blood cultures obtained during the review. The incidence of maternal infection was $2.56 / 10,000$ deliveries, while that of neonatal infection was $1.03 / 10,000$ live births. Postpartum fever and emergency caesarean section were often noted with maternal postpartum bacteroides bacteremia, while fetal distress, low Apgar scores and respiratory distress were frequent in neonatal bacteremia.

CONCLUSION: Postpartum bacteroides bacteremia should be suspected among women with postpartum fever after emergency caesarean section. However, the occurrence of postpartum fever following emergency caesarian section is not necessarily associated with neonatal bacteroides bacteremia. Neonatal bacteroides bacteremia may not be readily suspected on clinical grounds, so clinicians should ensure that the laboratory procedures routinely used to evaluate neonatal bacteremia at their institutions reliably detect these organisms.
\end{abstract}

Key Words: Bacteroides; Bacteroides fragilis; Neonate; Postpartum bacteremia; Sepsis

\section{Bactériémie à bacteroides chez le nouveau-né et la mère en période postpartum}

OBJECTIF : Un cas unique de bactériémie à Bacteroides fragilis chez une mère et son bébé est à l'origine d'une revue de ces infections néonatales et maternelles en période postpartum pendant une période de cinq ans dans deux établissements de Winnipeg, au Manitoba. L'objectif était de déterminer la fréquence de ces infections et d'établir les facteurs qui y sont généralement associés.

MÉTHODES : Les bébés et les mères en période postpartum chez qui un diagnostic de bactériémie à bacteroides a été posé, ont été identifiés à partir des dossiers de laboratoire dans les deux établissements puis, les dossiers médicaux de ces patients ont été passés en revue de façon rétrospective.

RÉSULTATS : Des espèces des bacteroides ont été isolées d'hémocultures de 10 mères et de quatre nouveau-nés. Ceci représentait 8,1\% d'hémocultures maternelles positives et 1,2\% d'hémocultures néonatales positives recueillies pendant l'étude. L'incidence d'infection maternelle était de 2,56/10 000 accouchements, alors que l'infection néonatale était de

voir page suivante

${ }^{1}$ Departments of Medical Microbiology and ${ }^{2}$ Pediatrics and Child Health, University of Manitoba, Winnipeg, Manitoba Correspondence: Dr Joanne E Embree, Department of Medical Microbiology, University of Manitoba, Room 530-730 William Avenue, Basic Medical Sciences Building, Winnipeg, Manitoba R3E OW3. Telephone 204-789-3630, fax 204-789-3926, e-mailEmbree@ms.UManitoba.Ca

Received for publication October 10, 1997. Accepted November 3, 1998 
1,03/10 000 naissances vivantes. La fièvre en postpartum et la pratique d'une césarienne d'urgence étaient souvent associées à une bactériémie à bactéroides chez la mère en postpartum, alors qu'une détresse fœtale, des indices d'Apgar bas et une détresse respiratoire étaient fréquents dans les cas de bactériémie néonatale.

CONCLUSION : On doit suspecter une bactériémie à bacteroides chez les femmes en postpartum accusant de la fièvre après avoir subi une césarienne d'urgence. Cependant, cette fièvre n'est pas obligatoirement associée à une bactériémie néonatale à bacteroides. La bactériémie néonatale à bacteroides peut ne pas facilement être décelée sur les seules bases cliniques, de sorte que les cliniciens devraient s'assurer que les techniques de laboratoire, utilisées de façon systématique pour évaluer une bactériémie néonatale dans leurs établissements, dépistent ces organismes de façon fiable.

W hile Bacteroides fragilis bacteremia is often seen in women during the puerperal period, we have rarely observed it as a cause of neonatal sepsis (1-10). However, despite its clinical rarity, $B$ fragilis was the third most common cause of neonatal bacteremia in one report, and the fourth most common isolate in another $(11,12)$. Chow et al (13) performed specific cultures for anaerobic bacteria, in which anaerobic organisms accounted for $26 \%$ of all neonatal bacteremias, with an incidence of 1.17 cases of $B$ fragilis infections per 1000 live births. The incidence of neonatal anaerobic infections may be underappreciated clinically because specific techniques for increased recovery and isolation of anaerobic bacteria are often not used routinely in the investigation of neonatal sepsis. Also, the clinical manifestations of neonatal anaerobic bacteremia may not be easily distinguishable from other causes of neonatal sepsis. In addition, anaerobic organisms may grow slowly in blood culture so that diagnosis may be delayed (1). Increased awareness of the role of these organisms in neonatal infection may contribute to more frequent detection of anaerobic infections in this age group. Because most bacteroides species are resistant to antibiotics routinely used empirically to treat neonatal sepsis and meningitis, determination of risk factors that predispose to neonatal anaerobical bacteremia would allow alteration of empirical antibiotic therapy to cover both aerobic and anaerobic organisms in these specific situations $(1,5,8,9,13,14)$. We present an unusual case in which both a mother and her infant became bacteremic with $B$ fragilis, as well as the experience with bacteroides infections in the neonatal and the postpartum maternal populations in the two teaching hospitals in Winnipeg, Manitoba.

\section{CASE PRESENTATION}

The mother was previously healthy, 22 years old, gravida 1, parida $O$ and married. She presented in labour at 36 weeks' gestation following an uneventful pregnancy. Labour duration was $13.5 \mathrm{~h}$, but $3 \mathrm{~h}$ before spontaneous vaginal delivery, the membranes were artificially ruptured, revealing thick meconium. The mother remained well until $36 \mathrm{~h}$ after delivery when she developed headache, malaise, fever of $38.9^{\circ} \mathrm{C}$ and signs of mild endometritis. Her peripheral blood count revealed a white blood cell count of $10,600 / \mathrm{mm}^{3}$ with $75.6 \%$ mature neutrophils, a hemoglobin of $10.6 \mathrm{~g} / \mathrm{L}$, and a platelet count of $181,000 / \mathrm{mm}^{3}$. Urine culture was negative, but a blood culture grew $B$ fragilis that was beta-lactamase-positive and sensitive to cefoxitin, pipercillin, clindamycin, chloramphenicol and metronidazole. Clindamycin and gentamicin had been started empirically but gentamicin was discontinued once the results of blood cultures were known. After three days of antibiotic therapy, the mother became afebrile and was discharged home three days later.

The liveborn male infant weighed $2860 \mathrm{~g}$ with Apgar scores of five at $1 \mathrm{~min}$ and eight at 5 mins. Vital signs were temperature of $36.4^{\circ} \mathrm{C}$, respiratory rate of 52 breaths/min and pulse of 125 beats/min. The infant was pale with hypotonia and moderate respiratory distress, and required intubation and artificial ventilation for $6 \mathrm{~h}$. His white blood cell count was $19,800 / \mathrm{mm}^{3}$ with $84.7 \%$ mature polymorphonuclear leukocytes and no immature forms. Hemoglobin was $15.1 \mathrm{~g} / \mathrm{L}$ and the platelet count was $213,000 / \mathrm{mm}^{3}$. The lumbar puncture was grossly bloody with 873 white cells $/ \mathrm{mm}^{3}$ and no organisms were seen on Gram stain. Urinalysis was normal. Chest radiograph was consistent with mild respiratory distress syndrome. Urine, meconium and cerebral fluid cultures were sterile, but a blood culture grew $B$ fragilis with an antibiotic susceptibility pattern identical to his mother's isolate. Antibiotics then were changed from empirical ampicillin and gentamicin to intravenous metronidazole. With this, the infant improved, and repeat blood cultures were sterile. Metronidazole was continued for 14 days.

\section{RETROSPECTIVE REVIEW}

Records of the Medical Microbiology Laboratories at the Health Sciences Centre and St Boniface Hospital, Winnipeg, Manitoba, were searched for bacteroides species recovered from blood cultures obtained from the neonatal units and the postpartum wards during the five-year period preceding this infant's birth. Prenatal status, labour and postpartum condition for each mother were evaluated, as well as the initial clinical status after birth, laboratory data and outcome of each neonate.

From these wards, 5250 blood cultures were submitted during the five-year period. In both institutions, blood for neonatal blood cultures is usually obtained by using a single PediBacT Alert (Organon Teknika Corporation, North Carolina) bottle, which is routinely vented. Generally, blood for maternal blood cultures is obtained in both anaerobic and aerobic culture media bottles. All blood cultures are processed using the BacT Alert Automated Incubator (Organon Teknika Corporation). Four hundred and forty-two (8.4\%) were positive for one or more organisms. Of these, $123(27.8 \%)$ were from postpartum mothers and 319 (72.2\%) were from neonates. Bacteroides species were isolated in $10(8.1 \%)$ of 123 positive maternal cultures and in four (1.2\%) of 319 positive neonatal cultures. This represents an incidence of 2.56 maternal infections/10,000 deliveries and 1.03 neonatal infections/10,000 live births. Details concerning the clinical factors reviewed 
TABLE 1

Maternal factors associated with postpartum bacteroides bacteremia

\begin{tabular}{|c|c|c|c|c|c|c|c|c|}
\hline & Organism & $\begin{array}{l}\text { Duration of } \\
\text { membrane } \\
\text { rupture (h) }\end{array}$ & $\begin{array}{c}\text { Amniotic } \\
\text { fluid }\end{array}$ & $\begin{array}{l}\text { Method } \\
\text { of delivery }\end{array}$ & $\begin{array}{c}\text { Number } \\
\text { of vaginal } \\
\text { examinations }\end{array}$ & $\begin{array}{c}\text { Temperature } \\
\text { in labour } \\
\left({ }^{\circ} \mathrm{C}\right)\end{array}$ & $\begin{array}{c}\text { Temperature } \\
\text { postdelivery } \\
\left({ }^{\circ} \mathrm{C}\right)\end{array}$ & $\begin{array}{c}\text { Hospital stay } \\
\text { (days) }\end{array}$ \\
\hline Case 1 & Bacteroides species & 18.5 & Normal & Emergency $\mathrm{C} / \mathrm{S}$ & 6 & 37.0 & 39.9 & 10 \\
\hline Case 2 & $\begin{array}{c}\text { Bacteroides capillosus + } \\
\text { Staphylococcus } \\
\text { epidermidis }\end{array}$ & 0.5 & Normal & Elective $\mathrm{C} / \mathrm{S}$ & - & 36.6 & 38.5 & 6 \\
\hline Case 3 & Bacteroides fragilis & Unknown & $\begin{array}{c}\text { Thick } \\
\text { meconium }\end{array}$ & Emergency $\mathrm{C} / \mathrm{S}$ & 5 & 36.4 & 38.6 & 9 \\
\hline Case 4 & Bacteroides ovatus & 41.5 & Meconium & Vaginal & - & 38.6 & 37.9 & 5 \\
\hline Case 5 & $\begin{array}{c}\text { B capillosus }+ \\
\text { peptostreptococcus }\end{array}$ & 0.5 & Normal & Emergency $\mathrm{C} / \mathrm{S}$ & 2 & 38.6 & 38.9 & 9 \\
\hline Case 6 & Bacteroides species & 3.0 & Normal & Vaginal & 3 & 37.0 & 40.0 & 13 \\
\hline Case 7 & $\begin{array}{c}\text { B fragilis }+ \\
\text { Enterococcus faecalis }\end{array}$ & 14.0 & Normal & Emergency $\mathrm{C} / \mathrm{S}$ & 2 & 37.3 & 39.6 & 13 \\
\hline Case 8 & B fragilis & 4.5 & Meconium & Vaginal & 3 & 37.8 & 39.0 & 6 \\
\hline Case 9 & $\begin{array}{c}\text { Bacteroides species } \\
\text { Coagulase-negative } \\
\text { staphylococcus }\end{array}$ & 16.0 & $\begin{array}{c}\text { Thick } \\
\text { meconium }\end{array}$ & Emergency $\mathrm{C} / \mathrm{S}$ & 3 & 37.0 & 38.8 & 9 \\
\hline Case 10 & $B$ fragilis & 32.0 & Normal & Vaginal & - & 39.0 & 39.7 & 15 \\
\hline
\end{tabular}

$\mathrm{C} / \mathrm{S}$ Caesarian section

TABLE 2

Neonatal factors associated with neonatal bacteroides bacteremia

\begin{tabular}{lcccc}
\hline & Case 1 & Case 2 & Case 3 & Case 4 \\
\hline Organism & $\begin{array}{c}\text { Bacteroides } \\
\text { fragilis }\end{array}$ & $\begin{array}{c}\text { Bacteroides } \\
\text { uniformis }\end{array}$ & B fragilis & B fragilis \\
Birth weight (g) & 765 & 3505 & 740 & 2860 \\
Sex & Female & Male & Female & Male \\
$\begin{array}{l}\text { Gestational age } \\
\text { (weeks) }\end{array}$ & 26 & 38 & 23 & 38 \\
$\begin{array}{c}\text { Duration of } \\
\text { membrane } \\
\text { rupture (h) }\end{array}$ & 104 & 7.5 & 3 & 4.5 \\
$\begin{array}{c}\text { Amniotic fluid } \\
\text { Normal }\end{array}$ & Meconium & Normal & Thick \\
$\begin{array}{l}\text { Method } \\
\text { of delivery }\end{array}$ & Vaginal & Vaginal & Forceps & Vaginal \\
$\begin{array}{l}\text { Apgar } \\
\text { (1 min) }\end{array}$ & 2 & 4 & 0 & 5 \\
\begin{tabular}{l} 
Outcome \\
\hline
\end{tabular} & Alive & Alive & Stillborn & Alive \\
\hline
\end{tabular}

from the 10 cases of maternal postpartum bacteroides bacteremia are described in Table 1, while those for the four cases of neonatal bacteroides bacteremia are described in Table 2 . All liveborn infants had respiratory distress immediately after birth. No infant had documented bacteroides meningitis. The index patients were the only maternal infant pair bacteremic for $B$ fragilis; however, $B$ fragilis was recovered from amniotic fluid cultures in the other two instances of neonatal $B$ fragilis bacteremia. One infant, who developed necrotizing enterocolitis, had a mixed infection with both $B$ fragilis and Escherichia coli.

\section{DISCUSSION}

The true incidence of neonatal bacteroides bacteremia is difficult to ascertain because specific anaerobic blood cultures are not routinely performed in neonates. However, because empirical therapy of neonatal sepsis is not usually adequate for these organisms, a high index of suspicion can assist in earlier identification and institution of appropriate therapy to decrease the associated high morbidity and mortality. The purpose of this investigation was to ascertain the frequency of bacteroides bacteremia in our populations and the potential factors associated with them.

Neonatal bacteroides bacteremia accounted for $1.2 \%$ of infant bacteremias and for $8.1 \%$ of bacteremias detected among postpartum women. This frequency of neonatal bacteroides bacteremia is similar to previous reports $(1.1 \%$ to $17 \%)$ despite the changes in nomenclature of this group of organisms that have occurred since they were published (14-16). However, the incidence of neonatal $B$ fragilis bacteremia was only 1.03 infections/10,000 live births, considerably lower than the 1.17 cases/1,000 live births reported by Chow et al (13) in 1974 , which is the only other reported incidence data. This may reflect differences in the patient populations studied, obstetrical care practices or the blood culture techniques used. There are no comparable maternal statistics.

Our index case is the only reported instance in which both the mother and infant were bacteremic with this organism. We did not detect any other case in the English literature indexed in MEDLINE and after reviewing the published papers cited in this report. That this is a rare event may reflect different risk factors predisposing postpartum and neonatal infections. Nine $(90 \%)$ of 10 mothers with bacteroides species bacteremia had postpartum fever (temperature $38.5^{\circ} \mathrm{C}$ or greater) and six $(60 \%)$ had caesarean section deliveries, which is consistent 
with previous reports $(3,17)$. Our neonatal patients with bacteroides bacteremia tended to be premature, had respiratory distress at birth if liveborn, and had Apgar scores at 1 min of age. Only the index pregnancy was complicated with postpartum endometritis, and that followed a vaginal, not a caesarean section, delivery. Also, only one pregnancy was complicated with prolonged rupture of placental membranes. Chow et al (13), in their study of 23 cases of neonatal anaerobic bacteremia, found that prematurity, fetal distress, Apgar scores at 1 min of age, foul odour at birth, respiratory distress, premature rupture of placental membranes and maternal amnionitis were the most commonly associated factors. In that study, 15 cases were due to bacteroides infection, of which six were $B$ fragilis. Importantly, eight of nine infants with a foul smell at birth were found to have bacteroides bacteremia. Foul smell was not commented upon by the caregivers in the instances of our patients. All of our bacteremic infants were delivered vaginally, whereas, in the study of Chow et al (13), eight (35\%) were delivered by caesarian section. They also found a significant correlation between perinatal aspiration of infected aniniotic fluid and the subsequent development of pneumonia or sepsis in the newborn infant. Of our three infants infected with $B$ fragilis, it was isolated from the amniotic fluid for two, supporting this as the usual mode of acquisition of this organism. Whether

\section{REFERENCES}

1. Harrod JR, Stevens DA. Anaerobic infections in the newborn infant. J Pediatr 1974;85:399-402.

2. Duff P. Pathophysiology and management of postcesarean endomyometritis. Obstet Gynecol 1986;67:269-76.

3. Bobitt JR, Ledger WJ. Amniotic fluid analysis. Its role in maternal neonatal infection. Obstet Gynecol 1978;51:56-62.

4. Dizerega GS, Yonekura ML, Keegan K, Roy S, Nakamura R, Ledger $\mathrm{W}$. Bacteremia in post-Cesarean section endomyometritis: differential response to therapy. Obstet Gynecol 1980;55:587-90

5. Law BJ, Marks MI. Excellent outcome of Bacteroides meningitis in a newborn treated with metronidazole. Pediatrics 1980;66:463-5.

6. Brook I. Osteomyelitis and bacteremia caused by Bacteroides fragilis: a complication of fetal monitoring. Clin Pediatr 1980;19:639-40.

7. Keffer GL, Monif GRG. Perinatal septicemia due to the Bacteriodacea. Obstet Gynecol 1988;71:463-5.

8. Berman BW, King FH Jr, Rubenstein DS, Long SS. Bacteroides fragilis meningitis in a neonate successfully treated with metronidazole. J Pediatr 1978;93:793-5.

9. Dysart NK, Griswold WR, Schanberger JE, Goscienski PJ, Chow AW. Meningitis due to Bacteroides fragilis in a newborn infant. J Pediatr 1976;89:509-10. this occurred in our index patient is unknown because amniotic fluid cultures were not obtained, but it seems likely.

The mortality due to bacteroides bacteremia during the neonatal period is substantial. In the study of Chow et al (13), only one infant with bacteroides species bacteremia died; thus, the mortality rate due to bacteroides infection was $7 \%$. In Brook's (15) 1994 review of the literature of neonatal anaerobic infections, the mortality rate due to bacteroides infections was $34 \%$ and that from other anaerobes was $17 \%$. Among our patients, one infant was stillborn but no liveborn infant died.

In summary, we have presented an unusual instance in which both a mother and her newborn infant became bacteremic with $B$ fragilis, and have shown that the diagnosis of this infection during the neonatal period is uncommon. We have also added four more cases to the neonatal literature that help confirm that fetal distress, respiratory distress and low Apgar scores at $1 \mathrm{~min}$ of age are factors associated with bacteroides infections in the neonate.

ACKNOWLEDGEMENTS: The authors thank the staff of the Microbiology Laboratories and the Medical Records Departments of the Health Sciences Centre and St Boniface Hospital for their assistance. We also thank Dr D Hoban, Dr T Williams and Dr DG Embree for their critical reviews of the manuscript.

10. Lombardi DP, Engleberg NC. Anaerobic bacteremia: Incidence, patient characteristics, and clinical significance. Am J Med 1992;92:53-60.

11. Gladstone IM, Ehrenkranz RA, Edberg SC, Baltimore RS. A ten-year review of neonatal sepsis and comparison with the previous fifty-year experience. Pediatr Infect Dis J 1990;9:819-25.

12. Weisman LE, Stoll BJ, Kueser TJ, et al. Intravenous immune globulin therapy for early onset sepsis in premature neonates. J Pediatr 1992;121:434-43.

13. Chow AW, Leake RD, Yamauchi T, Anthony BF, Guze LB. The significance of anaerobes in neonatal bacteremia: Analysis of 23 cases and review of the literature. Pediatrics 1974;54:736-45.

14. Noel GJ, Laufer DA, Edelson PJ. Anaerobic bacteremia in a neonatal intensive care unit: An eighteen-year experience. Pediatr Infect Dis J 1988;7:858-62.

15. Brook I. Anaerobic infections in the neonate. Adv Pediatr 1994;41:369-83.

16. Tyler $\mathrm{CW}$ Jr, Albers WH. Obstetric factors related to bacteremia in the newborn infant. Am J Obstet Gynecol 1966;94:970-6.

17. Goplerud CP, Ohm MJ, Galask RP. Aerobic and anaerobic flora of the cervix during pregnancy and the puerperium. Am J Obstet Gynecol 1976;126:858-65. 


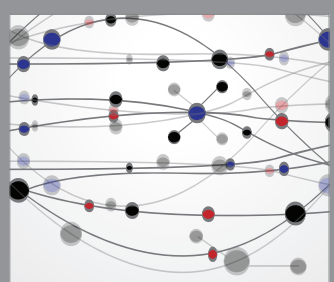

The Scientific World Journal
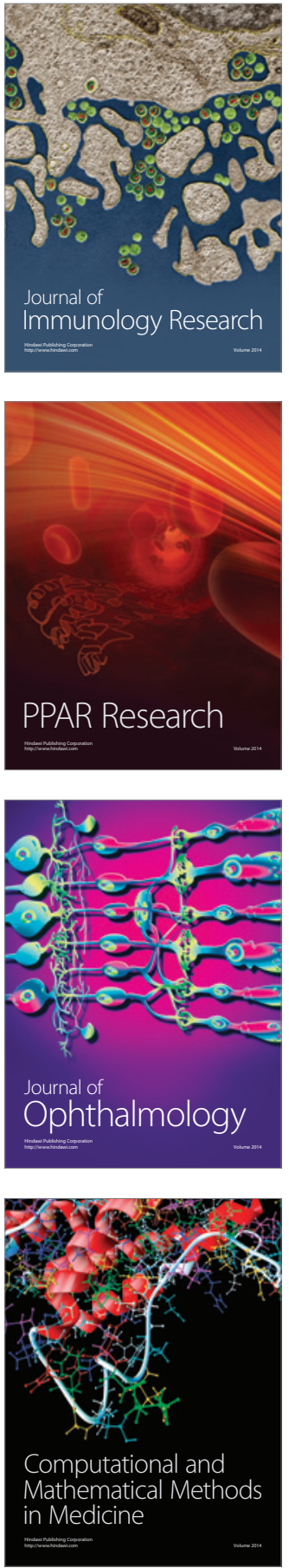

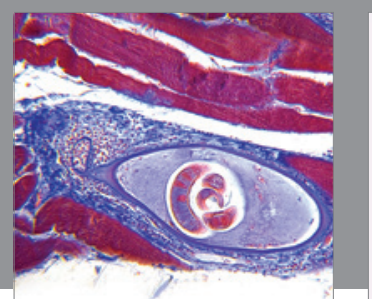

Gastroenterology Research and Practice

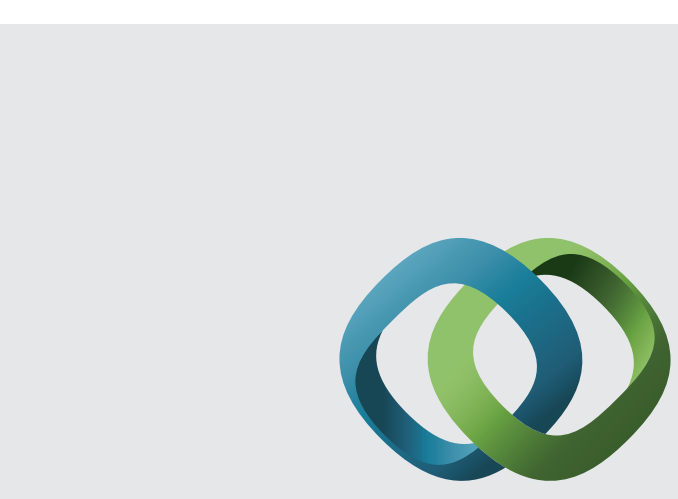

\section{Hindawi}

Submit your manuscripts at

http://www.hindawi.com
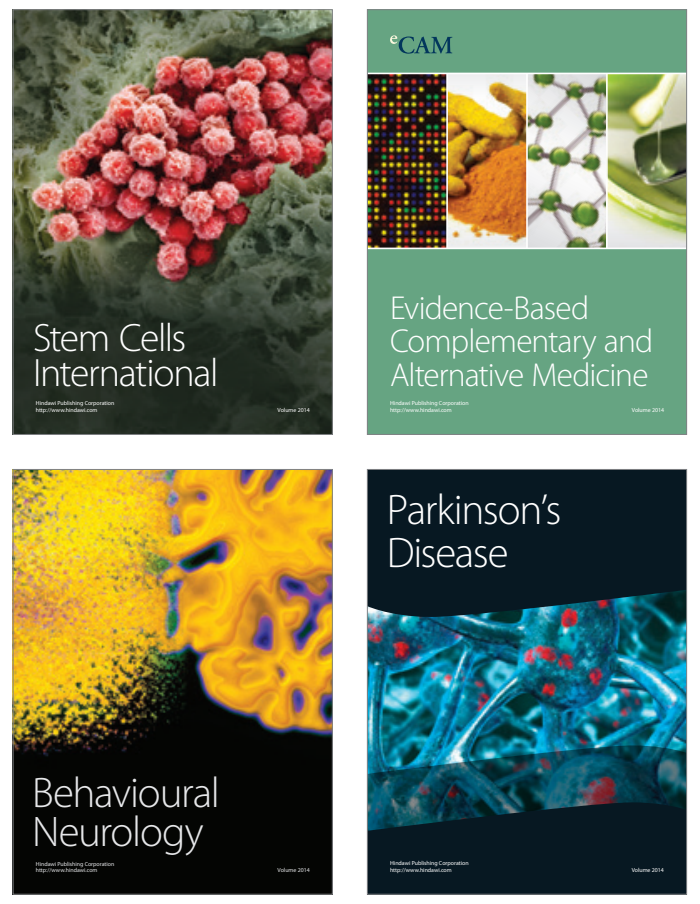
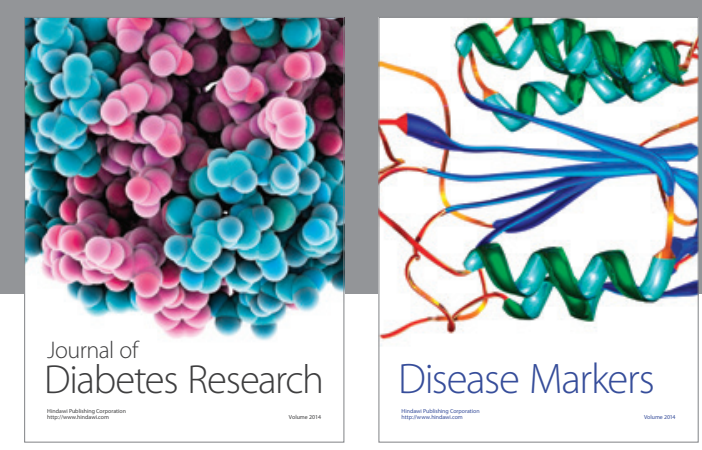

Disease Markers
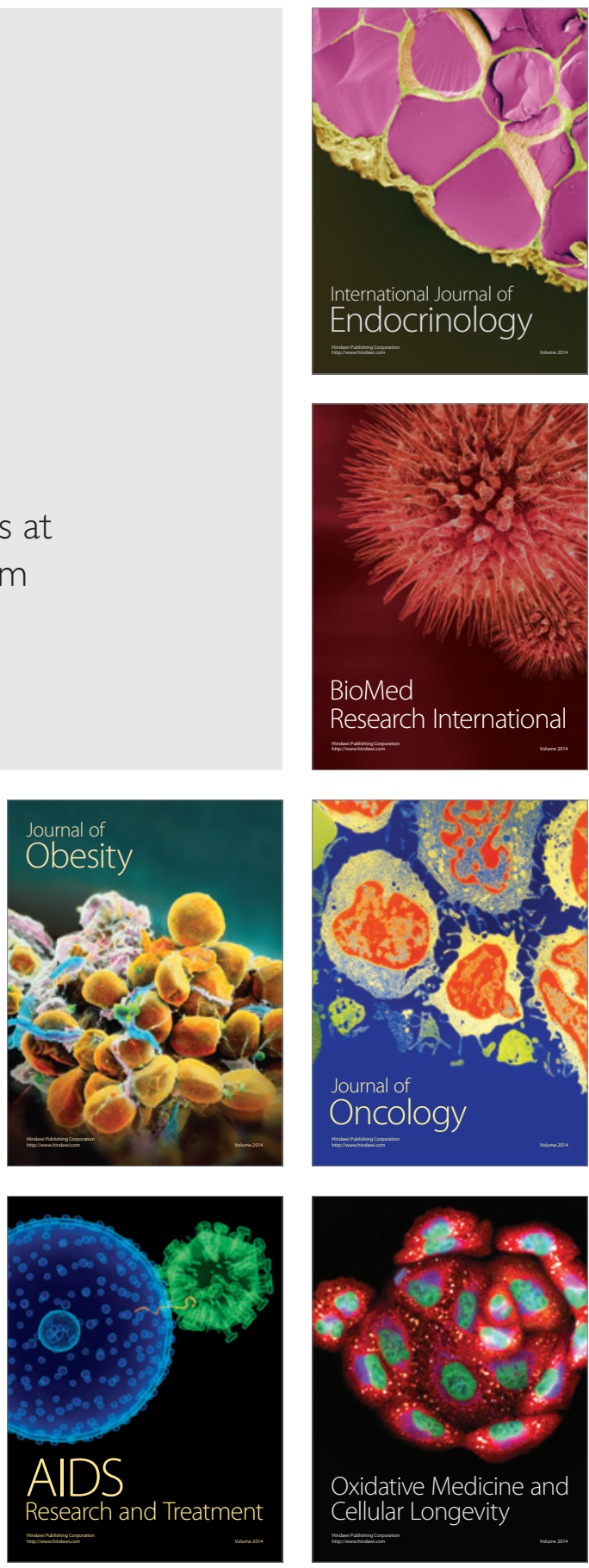